\title{
Explant position effect on gene transformation to flax (Linum usitatissimum L.) via Agrobacterium tumefaciens
}

\author{
RAMAZAN BEYAZ1 \\ MURAT AYCAN ${ }^{2}$ \\ MUSTAFA YILDIZ ${ }^{3}$ \\ ${ }^{1}$ Ahi Evran University, Faculty of Agriculture, \\ Department of Soil Science and Plant Nutrition, \\ 40100-Bagbasi, Kırsehir, Turkey \\ ${ }^{2}$ Ankara Univesity, Graduate School of Natural \\ and Applied Sciences, Department of Field Crops, \\ 06110-Dışkapı, Ankara, Turkey \\ ${ }^{3}$ Ankara University, Faculty of Agriculture, \\ Department of Field Crops, 06110-Dışkapı, Ankara, \\ Turkey \\ Correspondence \\ Ramazan BEYAZ \\ e-mail: ramazanbeyaz@gmail.com
}

Keywords: Agrobacterium tumefaciens, gene transfer, flax, explant position

Received January 03, 2017.

Revised July 07, 2017.

Accepted July 11, 2017.

\begin{abstract}
Background and purpose: In this study, it was aimed to determine the influence of the position where explant was taken, on gene transfer via Agrobacterium tumefaciens-mediated transformation in flax (Linum usitatissimum $L$.).
\end{abstract}

Materials and methods: In the study, three different hypocotyl explants, $0.5 \mathrm{~cm}$ long, were used according to the position where they were isolated from. Seven-day-old sterile seedlings having cotyledon leaves and no root system were inoculated with bacterial solution for 20 min. GV2260 line of Agrobacterium tumefaciens having 'pBIN 19' plasmid containing npt II gene and GUS reporter gene, was used in transformation studies. After inoculation, hypocotyl section of the seedlings was divided into 3 parts labeled with number 1 (part above the root), number 2 (part above number 1) and number 3 (part below cotyledon leaves) and these parts were left to co-cultivation for 2 days. Then, hypocotyl segments were transferred to selection medium containing antibiotics. The presence of npt-II (neomycin phosphotransferase II) gene in transformants was confirmed by PCR analysis.

Results: It was observed that the highest transgenic plant number was obtained from the explants taken from the region labeled 1, which was followed by explants taken from the region labeled 2. No transgenic plants could be obtained from explants isolated from region labeled 3.

Conclusions: This study showed that not only explant type but also the position explant was excised from is very important in gene transfer via Agrobacterium tumefaciens.

\section{INTRODUCTION}

Tn transgenic plant technology, the number of transgenic shoots and plants obtained should be high enough so that gene transfer studies can be deemed successful. As well as gene transfer to plants via $A$. Tumefacines, transgenic plant technology has superior advantages in comparison to other gene transfer methods, but also some restrictions. The most important of these is the host restriction. While gene transfer can easily be conducted to species such as tobacco, potatoes and eggplant that belong to the Solanaceae family, it is very difficult for gramineae, leguminous plants and tree species. Gene transfer to these plants via $A$. tumefaciens takes place at extremely low frequencies, and the plant regeneration from the cells to which the genes have been transferred also takes place at extremely low rates. Therefore, labor- and time-intensive efforts have been made to obtain transgenic plants for many plant spe- 
cies. For this reason, finding new methods that will increase the frequency of gene transfer in plants will facilitate the acquisition of transgenic plants, ensuring easier transfer of isolated genes to plants.

For plant species in which it is difficult to perform gene transfer via Agrobacterium tumefaciens, different practices can be carried out to increase the transformation frequency. Some of these routine practices include modifiying bacterial density and inoculation conditions, the optimization of co-cultivation periods and the use of different plant organs and cells. In addition to these practices, the addition of plant phenolic compounds such as acetosyringone to inoculate and co-cultivated mediums can significantly increase gene transfer in some plant species $(1,2)$. Phenolic compounds, secreted from injured plant cells, stimulate virulence genes located on the Ti plasmid in $A$. tumefaciens, and the enzymes that have been encoded by stimulated virulence genes carry out the T-DNA transfer from bacteria to plant cells.

In this study, the aim was to investigate the influence of the position where the explant was taken from in gene transfer via Agrobacterium tumefaciens-mediated transformation in flax (Linum usitatissimum L.). To the best of our knowledge, no such study has been carried out on flax before.

\section{MATERIAL AND METHOD}

\section{Plant Material}

Flax cultivar 'Madaras', supplied by Crop Science Laboratories (North Dakota, USA) was used as the plant material in this study.

\section{Explant Material}

Three different hypocotyl explants, each $0.5 \mathrm{~cm}$ long, were investigated based on the position where the explants were excised from. The hypocotyl section of the 7-day-old flax seedlings was divided into 3 regions labeled number 1 (part above the root), number 2 (part above number 1) and number 3 (part below the cotyledon leaves) (Figure 1).

\section{Seed Surface Sterilization}

Seeds were surface sterilized by continuously stirring in $40 \%$ commercial bleach -containing $5 \%$ sodium hypochlorite - at $10^{\circ} \mathrm{C}$ for 10 minutes and then washed three times with sterile water at the same temperature(3). Sterilized seeds were germinated in magenta vessels containing Murashige and Skoog (MS) growth medium, 3\% sucrose and solidified with $0.7 \%$ agar.

\section{Culture Conditions}

A growth medium (MS) containing MS mineral salts and vitamins (4), 3\% sucrose and $0.7 \%$ agar (Type A) was

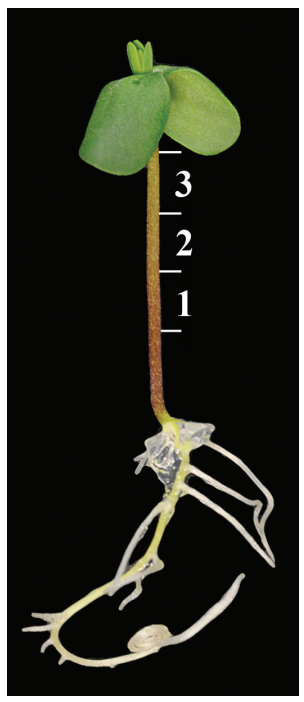

Figure 1. The positions where hypocotyl explants were isolated from

used. Distilled water was used in the medium preparation; hypocotyl explants were cultured in the MS medium containing $1 \mathrm{mgL}^{-1}$ of BAP and $0.02 \mathrm{mg} \mathrm{L}^{-1}$ of NAA for regeneration. After the $\mathrm{pH}$ of the medium was adjusted to 5.8 using $1 \mathrm{~N}$ of $\mathrm{NaOH}$ or $1 \mathrm{~N}$ of $\mathrm{HCl}$, it was sterilized by keeping it at an atmospheric pressure of 1.2 at $120^{\circ} \mathrm{C}$ for 20 minutes. All cultures were incubated at $24 \pm 1^{\circ} \mathrm{C}$ under a photoperiod of 16 hours of light and 8 hours of darkness using white fluorescent light of intensity $27 \mu \mathrm{mol} \mathrm{m} \mathrm{s}^{-1}$.

\section{Agrobacterium tumefaciens strain}

The Agrobacterium tumefaciens strain, GV2260, harboring plasmid p35S GUS-INT was used for inoculation. The binary plasmid p35S GUS-INT contains neomycin phosphotransferase II (npt-II) gene under control of nopathase (NOS) promoter and $\beta$-glucuronidase (GUS) gene controlled by cauliflower mosaic virus (CaMV35S) promoter. Agrobacterium tumefaciens strain GV2260 was taken from glycerol stocks stored at $-86^{\circ} \mathrm{C}$, and was grown overnight at $28^{\circ} \mathrm{C}$ in a rotary shaker $(180 \mathrm{rpm})\left(\mathrm{OD}_{600 \mathrm{~nm}}\right.$ $=0.6$ ) in the liquid NB (Nutrient Broth) medium containing $50 \mathrm{mg} \mathrm{L}^{-1}$ kanamycin and $50 \mathrm{mg} \mathrm{L}^{-1}$ rifampicin in $50 \mathrm{~mL}$ sterile falcon tubes. Then, $100 \mu \mathrm{L}$ of this culture was added to $10 \mathrm{~mL} \mathrm{NB}$ having antibiotics and incubated overnight at $28^{\circ} \mathrm{C}$ in a rotary shaker $(180 \mathrm{rpm})\left(\mathrm{OD}_{600 \mathrm{~nm}}\right.$ $=0.6$ ). Samples were taken from the bacterial cultures grown by using a loop, and were then spread over solid NA (Nutrient Agar) medium and left to grow for 2 days at $28^{\circ} \mathrm{C}$. The bacterial cultures developed in solid nutrient medium were stored at $+4^{\circ} \mathrm{C}$ for 2 months and used as required. The samples taken from bacterial cultures and used for gene transfer were put in the liquid NB medium containing only selective antibiotics in $50 \mathrm{ml}$ sterile falcon tubes, and were then used for gene transfer by re-growing overnight at $28^{\circ} \mathrm{C}$ in a shaking incubator. All bacterial 
growth mediums were supplemented with $50 \mathrm{mg} \mathrm{L}^{-1}$ of rifampicin and $50 \mathrm{mgL}^{-1}$ of kanamycine as the selected antibiotics.

\section{Transformation}

A. tumefaciens GV2260 carrying p35S GUS-INT plasmid was grown overnight and diluted with a liquid medium to $1 \times 10^{8} \mathrm{cell} \mathrm{ml}^{-1}$. Seven-day-old sterile seedlings having cotyledon leaves and no root system were dried with an air flow in a sterile cabin for 35 minutes in order to enable the seedlings to rapidly take in the bacterial solution towards the inner cells by employing the increased osmotic pressure of seedlings at the stage of inoculation, and, in this way, increase the number of cells inoculated and consequently increase the transformation efficiency as reported by Beyaz et al. (5). Then, the cut edges of the hypocotyl segment of the seedlings were immersed in liquid regeneration medium with $1 \mathrm{mg} \mathrm{L}^{-1}$ of BAP and $0.02 \mathrm{mg} \mathrm{L}^{-1}$ of NAA for 20 minutes with $500 \mu \mathrm{L}$ of bacterial solution for inoculation.

\section{Co-cultivation and selection}

The inoculated seedlings were divided into 3 parts labeled with number 1 (part above the root), number 2 (part above number 1) and number 3 (part below cotyledon leaves) and these parts were left to co-cultivation in MS medium containing $1 \mathrm{mg} \mathrm{L}^{-1} \mathrm{BAP}$ and $0.02 \mathrm{mg} \mathrm{L}^{-1}$ NAA for 2 days.

The explants, taken from co-cultivation, were placed in MS medium containing $1 \mathrm{mg} \mathrm{L}^{-1} \mathrm{BAP}$ and $0.02 \mathrm{mg}$ $\mathrm{L}^{-1} \mathrm{NAA}, 100 \mathrm{mg} \mathrm{L}^{-1}$ kanamycin, $500 \mathrm{~L}^{-1}$ duocid, and then they were cultured for 4 weeks.

\section{Genomic DNA extraction}

Genomic DNA was isolated from leaves of putative transgenic plants and from control (non-transformed) plants by the modification of the protocol described by Dellaporta et al. (6).

\section{Polymerase chain reaction (PCR)}

PCR amplification of the $n p t-I I$ genes was done with the following specific primers F: 5'-GCATACGCTTGATCCGGCTACC-3' and R: 5'-TGATATTCGGCAAGCAGGCAT- 3 ' for the $n p t-I I$ gene. PCR amplification of the chromosomal virulance gene $(c h v)$ was performed with the following primers F: 5'-CGAACCGCTGTTCGGCCTGTGG-3' and R: 5'-GTTCAGCAGGCCGGCATCCTGG-3' for detection of Agrobacterium tumefaciens contamination in putative transgenic plants.

Standard PCR was performed in $2 \mu \mathrm{L}$ containing 200 ng of DNA, 0.5 pmol of each primer, $0.25 \mu \mathrm{M} \mathrm{dNTP}, 1 \times$ PCR buffer, $2 \mathrm{mM} \mathrm{MgCl}$ and $0.625 \mathrm{U}$ of DreamTaq DNA polymerase (\#0702 Thermo). PCR was performed in a programmable thermocycler (MJ Research) with the following conditions: $5 \mathrm{~min}$ at $95^{\circ} \mathrm{C}$; followed by 36 cycles of denaturation for $1 \mathrm{~min}$ at $95^{\circ} \mathrm{C}$, annealing for $1 \mathrm{~min}$ at $58^{\circ} \mathrm{C}$, and extension for $1 \mathrm{~min}$ at $72^{\circ} \mathrm{C}$; and finally extantion with $10 \mathrm{~min}$ at $72^{\circ} \mathrm{C}$. Samples were then stored at $4^{\circ} \mathrm{C}$. Amplified DNA was detected by using ultraviolet light after electrophoresis on $1 \%$ agarose/ethidium bromide gels using $1 \times$ Tris-borate-EDTA as running buffer.

\section{Observations}

At the end of the culture, regeneration percentage, shoot number per explant, the highest shoot length in explant, total number of shoots growing in Petri dish, number of plantlet transferred to soil, the number of plant growing in soil, and PCR (+) plant number and transformation efficiency were determined.

\section{Confirmation of Transferred Genes in Plants}

The confirmation of gene transfer was performed by PCR method. According to Dellaporta et al. (6); genomic DNA was isolated from fresh leaf tissues in the PCR method. Leaf samples were taken from plants obtained by growing plantlets in vases, previously grown in tissue culture, and thus bacterial-arising contamination risk was reduced. Also, the existence of $c h v$ virulence gene included in the chromosome of Agrobacterum tumefaciens was investigated by means of primary, using the protocol, reported by Yang et al. (7) to be available in the samples taken during the PCR reaction. If the band belonging to the gene wasn't seen in gel, it was understood that there was no bacterial contamination. Afterwards, the genes, transferred by using transferred gene-specific primers, were reproduced in appropriate PCR conditions. Negative (plants without gene transfer) and positive (plasmid DNA) control were also used in the study. After PCR, the reactions were analyzed by loading to agarose gel.

\section{Statistical Analysis}

Five replicates were tested. Petri dishes $(100 \times 10 \mathrm{~mm})$ containing 20 explants. One-way Analysis of Variance (ANOVA) was used to test the effect of e3xplant position on transformation efficiency. All experiments were repeated two times. Data were statistically analyzed by „SPSS for Windows" computer program. Duncan's multiple range test was used to compare the means. Data presented in percentages were subjected to arcsine $(\sqrt{X})$ transformation before statistical analysis (8).

\section{RESULTS AND DISCUSSION}

The most commonly used vector for gene transfer in plants is the bacteria Agrobacterium tumefaciens. A.tumefaciens is known as a "natural genetic engineer of plants" due to this trait (9). The Agrobacterium-mediated transformation method has been a widely used gene transfer method. The advantages of the method are a wide 
Table 1. The gene transformation to explants which were taken from three different positions of the hypocotyl region of the 7-day-old sterile flax seedlings

\begin{tabular}{|lcccccccc|}
\hline $\begin{array}{l}\text { Explant } \\
\text { Position }\end{array}$ & $\begin{array}{c}\text { Shoot } \\
\text { regeneration } \\
(\%)\end{array}$ & $\begin{array}{c}\text { Shoot number } \\
\text { per explant }\end{array}$ & $\begin{array}{c}\text { The highest } \\
\text { shoot length } \\
(\mathrm{cm})\end{array}$ & $\begin{array}{c}\text { Total shoot } \\
\text { number per } \\
\text { Petri dish }\end{array}$ & $\begin{array}{c}\text { Number } \\
\text { of plantlet } \\
\text { transferred } \\
\text { to soil }{ }^{1}\end{array}$ & $\begin{array}{c}\text { Plant number } \\
\text { growing } \\
\text { in soil }\end{array}$ & $\begin{array}{c}\text { PCR }(+) \\
\text { plant number } \\
\text { after } c h v \text { gene } \\
\text { analysis }\end{array}$ & $\begin{array}{c}\text { Transformation } \\
\text { Efficiency }(\%) \\
(2 / 1 \times 100)\end{array}$ \\
\hline 1 & $96.65 \pm 1.33 \mathrm{a}$ & $1.65 \pm 0.10 \mathrm{a}$ & $4.46 \pm 0.35 \mathrm{a}$ & $31.66 \pm 1.85 \mathrm{a}$ & $31.00 \pm 1.53 \mathrm{a}$ & $31.00 \pm 1.53 \mathrm{a}$ & $29.00 \pm 2.00 \mathrm{a}$ & 93.54 \\
2 & $23.33 \pm 1.20 \mathrm{~b}$ & $1.18 \pm 0.09 \mathrm{~b}$ & $2.57 \pm 0.22 \mathrm{~b}$ & $6.33 \pm 0.26 \mathrm{~b}$ & $6.00 \pm 0.58 \mathrm{~b}$ & $6.00 \pm 0.58 \mathrm{~b}$ & $4.00 \pm 1.00 \mathrm{~b}$ & 66.66 \\
3 & $5.00 \pm 0.58 \mathrm{c}$ & $1.00 \pm 0.12 \mathrm{c}$ & $0.32 \pm 0.03 \mathrm{c}$ & $1.00 \pm 0.00 \mathrm{c}$ & $1.00 \pm 0.00 \mathrm{c}$ & $0.00 \pm 0.00 \mathrm{c}$ & $0.00 \pm 0.00 \mathrm{c}$ & 0.00 \\
\hline
\end{tabular}

Each value is the mean of 5 replicates containing 20 explants per replicate. All experiments were repeated 2 times.

Regeneration percentage means the number of explants having shoots out of 20 explants cultured in a Petri dish.

Transformation efficiency means the number of PCR (+) plants out of number of plantlet transferred to soil.

Values within a column for each cultivar followed by different letters are significantly different at the 0.01 level

1. Hypocotyl part above the root,

2. Hypocotyl part above number 1 ,

3. Hypocotyl part below cotyledon leaves

range of host plants, including agronomically and horticulturally important crops such as soybean, cotton, rice, wheat, flowers and various trees (10) and being able to transfer a small number of copies of the T-DNA (transferDNA) into the cytoplasm, resulting in stable integration into the plant chromosomes. Although it has merits over other transformation methods like particle bombardment, electroporation and silicon carbide fibers, it is still hard to achieve a high transformation efficiency and gene expression using this method.

In order to have greater success in gene transformation, the shoot regeneration - and especially the number of regenerated shoots per explant - must be high. But, the greatest problem in gene transformation studies using Agrobacterium tumefaciens is that transgenic shoot frequency is low due to the defense mechanism developed by plants against pathogenic attack. Therefore, alternative methods should be developed in order to obtain high transgenic shoot and plant frequencies in gene transformation studies. When Agrobacterium tumefaciens, a pathogen, has carried out an attack, the plant tries to resist this attack and activates its defense mechanism, and it tries to get over it with minimum loss. The regeneration capacity of plant tissues considerably decreases after an Agrobacterium tumefaciens infection due to the plant's defense mechanism. For this reason, it is a tremendous success to increase gene transfer frequency by even $1 \%$. To increase gene transfer frequency, changes in parameters such as bacterial density and duration of inoculation are made. Vacuum infiltration is a method applied to increase the transgenic shoot frequency, and it allows bacteria to reach more cells with negative atmospheric pressure created in the tissue, and thus, it is aimed to increase the number of gene transferred cells and shoots. Different applications of the inoculation method can significantly increase transgenic shoot frequency.
Flax regenerates easily from hypocotyl segments under in vitro conditions $(11,12,13,14,15)$. However, the recovery of transgenic flax plants $(13,16)$. When hypocotyl segments were directly inoculated, transgenic shoot frequency was extremely low due to the plant's defense mechanism caused by the pathogenic attack by the Agrobacterium infection (17).

In their study, Beyaz et al. (5) compared the routinely used inoculation method -involving the transfer of hypocotyl explants of flax (Linum usitatissimum L.) to cocultivated medium after being inoculated with the bacteria for a certain period of time - with a new inoculation method. In the newly described inoculation method, 7-day-old sterile flax seedlings containing cotyledon leaves were dried in an air flow within a sterile cabin for 35 minutes. The reason why 7-day-old seedlings with cotyledon leaves were dried with an air flow in a sterile cabin was to increase the osmotic pressure of the seedlings so that the bacterial solution was drawn to the inner cells during the inoculation phase. This increases the number of cells to which the gene was transferred and consequently improves the transgenic shoot frequency. In this method, the dried flax seedlings with cotyledon leaves were inoculated with $500 \mu$ l of bacterial solution added to the liquid regeneration medium for 20 minutes. Then, hypocotyl explants isolated from inoculated seedlings were transferred to co-cultivated medium for 2 days, and were then cultured for regeneration in selected medium containing antibiotics for 4 weeks. At the end of the study, the best results for all parameters examined were obtained from the newly described inoculation method - based on inoculation of 7-day-old sterile seedlings having cotyledon leaves without a root system and dried in a sterile cabin for 35 minutes.

The highest results of all the characters examined were obtained from hypocotyl explants taken from the region 


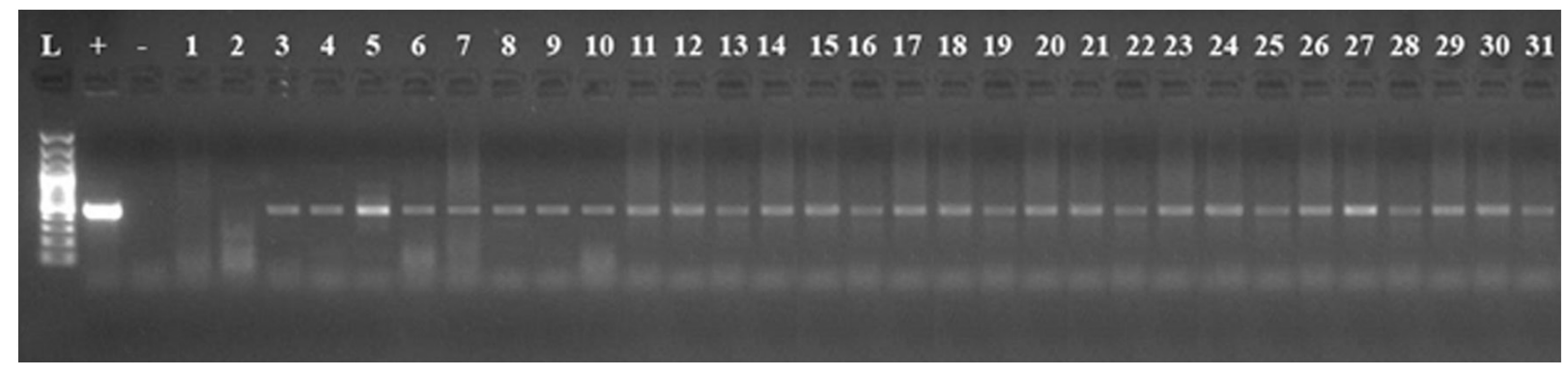

Figure 2. PCR analysis of genomic DNA from putative transgenic plants cv. 'Madaras' developed from hypocotyl explants taken from the position 1 for amplification of $458 \mathrm{bp} n p t-I I$. L DNA ladder $100 \mathrm{bp},+$ Plasmid as a positive control, - Water as a negative control, $1-31$ putative transgenic plants

1 , while the worst results were recorded from the explants taken from region 3. This is probably because the bacterial flow into hypocotyl region 3 was lower than that of region 1 . Region 1 was directly in contact with the inoculation environment and gene transition to the cells in this region was higher (Table 1). The regeneration percentage was recorded as 96.65 in region 1 , while it was only 5.00 in region 3 . The shoot number per explant, the highest shoot length, total shoot number per Petri dish, number of plantlet transferred to soil, plant number growing in soil and PCR $(+)$ plant number were recorded as 1.65 , $4.46 \mathrm{~cm}, 31.66,31.00,31.00$ and 29.00 in region 1, while $1.00,0.32 \mathrm{~cm}, 1.00,1.00,0.00$ and 0.00 in region 3 , respectively (Table 1). Thirty-one of the plantlets growing from the hypocotyl explant taken from region 1 were transferred into soil; all of them grew and generated plants, and the PCR (+) plant number was determined to be 29 (Figure 2). Six plantlets taken from region no 2,were transferred into soil; all of them grew and the PCR (+) plant number was determined to be 4 (Figure 3). Only 1 plantlet, which was taken from the region 3 , was transferred to soil, but no plants grew at all. Transformation efficiency was obtained as $93.54 \%$ in hypocotyl region 1 while it was 66.66 in region 2.

In the study conducted by Beyaz et al. (5), the mean transformation efficiency was reported to be $30.45 \%$ in

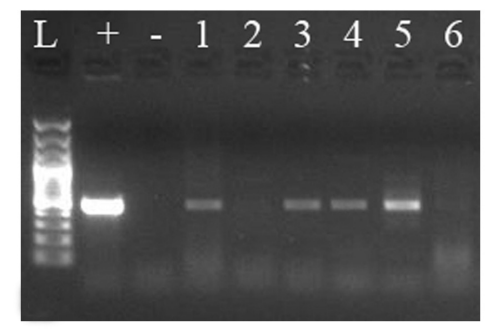

Figure 3. PCR analysis of genomic DNA from putative transgenic plants $\mathrm{cv}$. 'Madaras' developed from hypocotyl explants taken from the position 2 for amplification of $458 \mathrm{bp} n \mathrm{nt}$-II. L DNA ladder $100 \mathrm{bp},+$ Plasmid as a positive control, - Water as a negative control, 1-6 putatitve transgenic plants the routine inoculation method in which hypocotyl explants excised from 7-day-old sterile flax seedlings were directly inoculated with a $500 \mu \mathrm{L}$ bacterial solution for 20 minutes. In the newly described inoculation method, the highest mean transformation efficiency was found to be $84.19 \%$. In our study, we used the same inoculation method developed by Beyaz et al. (5). In addition to this protocol, different positions of the hypocotyl region from 7-day-old sterile seedlings were used. That was why the transformation efficiency in our study $(93.54 \%)$ was found to be higher than the $84.19 \%$ in the study by Beyaz et al. (5).

The presence of the $c h v$ gene was checked through the analysis performed to determine bacterial contamination, and accordingly, it was confirmed that bacterial contamination didn't exist in any plants developed from the hypocotyl explants taken from regions 1 and 2; in other words, all the plants were transgenic.

\section{CONCLUSIONS}

Agrobacterium tumefaciens, as a plant pathogen, has been widely used for the introduction of foreign genes into plants and the consequent regeneration of transgenic plants. The success of genetic transformation via Agrobacterium tumefaciens is limited due to the fact that the plant's defence mechanism will be actived when the pathogen attacks. That is why manipulations of the plant, bacteria and physical conditions have been applied to increase the virulence of the bacteria and to increase the transformation efficiency. This study showed that not only the explant type but also the position the explant was excised from is very important in gene transfer via Agrobacterium tumefaciens.

\section{REFERENCES}

1. SUNILKUMAR G, VIJAYACHANDRA K, VELUTHAMBI K 1999 Preincubation of cut tobacco leaf explants promotes Agrobacterium-mediated transformation by increasing vir gene induction. Plant Sci. 141: 51-58.

https://doi.org/10.1016/S0168-9452(98)00228-3 
2. ÇÖÇÜ S 2009 Production of Insect-Resitant Transgenic Sainfoin (Onobrychis sativa Lam.) Plants. Ankara University, Graduate School of Natural and Applied Sciences, Department of Field Crops, Ph.D. Thesis.

3. YILDIZ M, ER C 2002 The effect of sodium hypochlorite solutions on in vitro seedling growth and shoot regeneration of flax (Linum usitatissimum). Naturwissenschaften 89: 259-261.

https://doi.org/10.1007/s00114-002-0310-6

4. MURASHIGE T, SKOOG F 1962 A revised medium for rapid growth and bioassays with tobacco tissue cultures. Physiol. Plant. 15: 473-497. https://doi.org/10.1111/j.1399-3054.1962.tb08052.x

5. BEYAZ R, DARÇIN E S, AYCAN M, KAYAN M, YILDIZ M 2016 A novel method for high-frequency transgenic shoot regeneration via Agrobacterium tumefaciens in flax (Linum usitatissimum L.). Journal of Plant Biotechnology 43: 240-247.

6. DELLAPORTA S L, WOOD J, HICKS J B 1983 A plant DNA miniprepration: version II, Plant Mol. Biol. Rep. 4: 9-21.

7. YANG L, WANG C, WANG L, XU C, CHEN K 2013 An efficient multiplex PCR assay for early detection of Agrobacterium tumefaciens in transgenic plant materials, Turk. J. Agric. For. 37: 157-162.

8. SNEDECOR GW, COCHRAN WG 1967Statistical Methods. The Iowa State University Press, Iowa, USA.

9. OZCAN S, OZGEN M 1996 Plant genetic engineering, Journal of KÜKEM. 1: 69-95.

10. LOPEZ SJ, KUMAR RR, PıUS PK, MURALEEDHARAN N 2004 Agrobacterium tumefaciens-mediated genetic transformation in tea (Camellia sinensis [L.] O. Kuntze). Plant Mol. Biol. Rep., 22:201a-201j.

11. GAMBORG OL, Shyluk J P 1976 Tissue culture, protoplasts, and morphogenesis in flax. Bot. Gaz. 137: 301-306.

12. MATHEWS VH, NARAYANASWAMY S 1976 Phytohormone control of regeneration in cultured tissues of flax. Zeitschrift für Pflanzenphysiologie 80: 436-442. https://doi.org/10.1016/S0044-328X(76)80191-2

13. DONG J, MC HUGHEN A 1993 An improved procedure for production of transgenic flax plants using Agrobacterium tumefaciens. Plant Sci 88: 61-71. https://doi.org/10.1016/0168-9452(93)90110-L

14. FRIEDT W 1990 Biotechnology in breeding of industrial oil crops: the present status and future prospects. Fat Science Technology 90: 51-55.

15. MILLAM S., DAVIDSON D. and POWELL W 1992. The use of flax (Linum usitatissimum) as a model system for studies on organogenesis in vitro: the effect of different carbonhydrates. Plant Cell, Tissue and Organ Culture 28: 163-166. https://doi.org/10.1007/BF00055512

16. BERANOVA M, RAKOUSKY S, VAVROVA Z, SKALICKY T 2008 Sonication assisted Agrobacterium-mediated transformation enhances the transformation efficiency in flax (Linum usitatissimum L.). Plant Cell, Tissue Organ Cult. 94: 253-259. https://doi.org/10.1007/s11240-007-9335-z

17. JORDAN M C, MC HUGHEN A 1988 Transformed calllus does not necessarily regenerate transformed shoots. Plant Cell Rep. 7: 285-287. 